- во-вторых, отчуждения прав (уступки прав) на доменное имя, предполагающее заключение обладателем прав на доменное имя с другим лицом соглашения, которое становится основанием для внесения в реестр доменных имен изменений и влечет за собой переход прав на доменное имя от первого лица ко второму;

- в-третьих, предоставления иному лицу права использовать доменное имя на условиях, предусмотренных соответствующим договором, что не предполагает переход (передачу) прав на доменное имя от одного лица к другому.

Исходя из вышесказанного, реализуя выше перечисленные права, правообладатель тем самым реализует свои имущественные права, в том числе право распоряжения, пользования, извлекая полезные свойства, приобретая различные выгоды от доменного имени.

По своей природе, право на доменное имя схоже с исключительным правом на средство индивидуальности, однако исходя из логики законодателя таковым не является.

1. Гражданский кодекс Российской Федерации (часть четвертая) от 18.12.2006 № 230-Ф3 // Собрание законодательства РФ, 25.12.2006, № 52 (1 ч.), ст. 5496.

2. Федеральный закон от 27.07.2006 № 149-Ф3 «Об информации, информационных технологиях и о защите информации» // Собрание законодательства РФ, 31.07.2006, № 31 (1 ч.), ст. 3448.

3. Постановление ЕСПЧ от 18.09.2007 по делу «Паеффген против Германии» (Paeffgen GMBH v. Germany; application no. 25379/04, 21688/05, 21722/05, 21770/5).

4. Постановление Президиума ВАС РФ от 16.01.2001 № 1192/00 по делу № А40-25314/99-15-271 // Вестник ВАС РФ, 2001, № 5.

5. Решение АС г. Москвы от 03.11.2011, постановление 9-го ААС от 20.02.2012 по делу № А4073876/11-12-626 // СПС Консультант Плюс.

6. Решение Арбитражного суда г. Москвы от 20 января 2015 г. по делу № А40-178919/2014 // СПС Консультант Плюс.

7. Гладкая Е.И. Правовой режим доменного имени в России и США: Дис. ... канд. юрид. наук. М., 2014.

8. Кожемякин Д.В. Доменное имя в системе объектов гражданских прав: монография. М.: Проспект, 2019. $152 \mathrm{c}$.

9. Правила регистрации доменных имен в доменах .RU и .PФ // Официальный сайт Координационного центра национального домена сети Интернет: https://cctld.ru/files/pdf/docs/rules_ru-rf.pdf.

10. Рожкова М.А. Право в сфере Интернета: сборник статей / М.З. Али, Д.В. Афанасьев, В.А. Белов и др.; рук. авт. кол. и отв. ред. М.А. Рожкова. М.: Статут, 2018. 528 с.

11. Сводная статистика зоны.RU- Режим доступа: URL: https://statonline.ru/?tld=ru.

12. Цыбаков Д.Л., Внуков Н.А., Абрамов С.А. Проблема правового регулирования интеллектуальных прав на доменное имя // Вестник арбитражной практики. - 2017. - № 5. - С. 65 - 71.

13. Яганов А.А. К вопросу о соотношении исключительного права на товарный знак и права на доменное имя // ИС. Авторское право и смежные права. - 2020. - № 9. - С. 59 - 70.

\title{
Упоров И.В. \\ Выборы и статус депутата местного Совета в советском государстве (до Конституции СССР 1977 г.): правовой аспект
}

Краснодарский университет МВД России

(Россия, Краснодар)

doi: 10.18411/lj-04-2021-255

\section{Аннотация}

Раскрываются основные тенденции развития статуса депутата в советском государстве в период до принятия Конституции СССР 1977 г., при этом акцент делается на статусе местных Советов. Отмечается, что с формально точки зрения 
депутаты являлись представителями народа во властных структурах и имели соответствующие полномочия, довольно подробно отрегулированные в законах, особенно в начале 1970-х гг. Однако фактически депутаты избирались на безальтернативной основе и соответственно их потенциал в условиях командноадминистративной системы управления обществом использовался далеко не в полном объеме. Автор использовал свои более ранние публикации по этой теме.

Ключевые слова: Советы, депутат, статус, выборы, закон, общество, государство, избиратели.

\section{Abstract}

The article reveals the main trends in the development of the status of a deputy in the Soviet state in the period before the adoption of the Constitution of the USSR in 1977, with an emphasis on the status of local Soviets. It is noted that from a formal point of view, the deputies were the representatives of the people in the power structures and had the appropriate powers, regulated in some detail in the laws, especially in the early 1970s. However, in fact, the deputies were elected on an uncontested basis and, accordingly, their potential under the conditions of the command-administrative system of public administration was far from being used in full.

Key words: Councils, deputy, status, elections, law, society, state, voters.

До Октябрьской революции 1917 г. правовое положение народных представителей на уровне местного самоуправления не регулировалось - законодатель ограничивался лишь вопросами компетенции всего представительного органа местного самоуправления (в империи таковыми были земские и городские собрания). На законодательном уровне не был определен правовой статус и депутата Государственной думы - органа, начавшего функционировать с 1906 г. После Октябрьской революции 1917 г. советская власть самого начала придавала большое значение вопросам организации местного управления - так, уже в Конституции РСФСР 1918 г. [1] провозглашалось, что вся власть в центре и на местах принадлежит Советам, которые состояли из избираемых депутатов рабочих, крестьянских, солдатских и казачьих депутатов (в литературе и документах использовалось сокращенное понятие «Советы», а позднее в Конституции СССР 1936 г. была найдена обобщенная формулировка - «Советы депутатов трудящихся», но в практике по-прежнему часто использовалось сокращенное название «Советы»).

В советском государстве с самого начала отношения народного представительства во власти были поставлены как приоритетные. При этом однако согласно политико-идеологической доктрине большевиков это представительство было неравным (довлел классовый признак). Кроме того, выборы депутатов в Советы по большей части непрямыми - так, поскольку выборы делегатов на Всероссийские съезды Советов производились от депутатов городских и губернских съездов Советов в соответствии с установленной Конституцией РСФСР нормой, то есть депутаты фактически являлись не представителями населения, а представителями Советов. Прямые выборы устанавливались только при избрании депутатов в городские и сельские Советы. Следует заметить, что уже тогда советский законодатель ввел норму об отзыве депутата (и таковая будет включаться во все последующие акты советского избирательного права). Так, Конституция РСФСР 1918 г. содержала норму (ст. 78), согласно которой «избиратели, пославшие в Совет депутата, имеют право во всякое время отозвать его и произвести новые выборы согласно общему положению» [1], причем такая норма будет включаться затем во все советские конституции. Уточнял эту норму Декрет о праве отзыва делегатов от 24 ноября 1917 г., где, в частности, определялось, что «ни одно выборное учреждение не может считаться истинно демократическим и действительно представляющим волю народа, если отсутствует 
право отзыва избирателями своих выборных» [2]. Согласно Декрету съезд Советов имел право назначать перевыборы во всякие представительные учреждения. Кроме того, по требованию более чем половины избирателей соответствующего избирательного округа Советы должны были назначать перевыборы. Вновь избранные представители с момента избрания замещали прежде избранных.

В дальнейшем в отдельных актах начинают появляться нормы (пока еще разрозненные), характеризующие правовой статус депутата. Так, во время Гражданской войны VII съезд Советов принял резолюцию «О советском строительстве» (1919 г.), где выдвигалось требование активизации работы всех депутатов Советов, в частности, каждый член Совета «во что бы то ни стало» обязан был не реже одного раза в две недели отчитываться перед своими избирателями. Член Совета, дважды не исполнивший указанной обязанности по неуважительным причинам, лишался мандата. На его место избирался новый депутат. Сам отзыв осуществлялся на собрании избирателей простым большинством голосов, при этом принятое решение являлось окончательным и обжалованию по существу не подлежало [3]. Позже было принято специальное постановление ВЦИК «Об отзыве депутата» (1928 г.), где указывалось, что «право отзыва депутата их избирателями является одной из важнейших форм советской демократии» [4]. Здесь интерес представляет перечень обязанностей депутата местного Совета, за неисполнение которых, собственно, он мог быть отозван, причем этот перечень отражен недостаточно четко, можно даже сказать, приблизительно, но, тем не менее, некоторые из них обозначены вполне предметно, в том числе депутат был обязан: систематически посещать заседания Совета, секций и комиссий; выполнять поручения Совета или его Президиума; принимать меры к выполнению наказов избирателей; не допускать недопустимого для депутата поведения.

В Конституции СССР 1936 г. [5] избирательное право провозглашалось всеобщим равным и прямым. Не обладали им только умалишенные и лица, осужденные судом с лишением избирательных прав (ст. 134, 135 Конституции СССР. Выборы депутатов всех уровней производились гражданами непосредственно. Что касается статуса депутата, то новеллой являлась норма ст. 52 Конституции СССР 1936 г., провозглашавшая депутатский иммунитет: депутат не мог быть привлечен к судебной ответственности или арестован без согласия Верховного Совета СССР, а в период между сессиями, - без согласия Президиума Верховного Совета СССР. Так стал формироваться институт неприкосновенности депутата. Сначала в этой Конституции СССР речь шла лишь о депутате Верховного Совета - высшего представительного органа государственной власти, однако в дальнейшем законодательство стало регламентировать неприкосновенность депутатов всех уровней.

К тому времени в стране уже была сформирована административно-командная система управления, в рамках которой Советы всех уровней являлись собой соподчиненную вертикаль законодательной власти. Соответственно и депутаты всех уровней действовали строго в духе правящей идеологии. Соответственно произошло окончательное огосударствление местной власти. Такое положение вызывало резкую критику и неприятие в нелегальной политической литературе. Так, ставшим оппозиционером к советской власти М.Н. Рютин при изложении платформы «Союза марксистов-ленинцев» в 1932 г. специальный раздел посвятил «кризису советов и приводных ремней пролетарской диктатуры». Он отмечал, что «выборность Советов в огромной, подавляющей степени заменена, по существу, назначенством. В Советах ныне сидят люди, прислушивающиеся не к голосу масс, а только к голосу начальства, смотрящие не вниз, а вверх, люди, которые по приказанию начальства готовые учинить какой угодно произвол и насилие над массами, прикрываясь именем и волей этих масс» [6, с. 430]. В качестве вывода было сформулировано следующее положение: «советы из органов, в которых выражалась воля, настроения и подлинные желания широчайших 
партийных и беспартийных рабочих масс и бедняцко-середняцкой части деревни ... превратились в органы подавления воли этих масс» [6, с. 431]. Тем не менее формально депутаты отражали принцип народовластия, а данная точка зрения представляется все же крайней и явно политизированной. Вместе с тем обеспокоенность М.Н. Рютина имела под особой основания. Так, хотя избирательное законодательство допускало выдвижение альтернативных кандидатов в депутаты, в действительности этого не происходило, и выдвигался единственный кандидат, который предварительно обсуждался местными парторганизациями ВКП (б). Тем самым большевики, сумевшие получить монополию своей политики и идеологию в стране, обеспечивали полное и безальтернативное представительство своих сторонников во всех властных структурах.

Сформированное перед Великой Отечественной войной законодательство о Советах функционировало довольно долго - вплоть до второй половины 1960-х гг. До этого принципиальных изменений не было. Вместе с тем принимались отдельные акты, регулирующие отдельные стороны правового статуса депутата, в том числе депутата местного Совета. Собственно, на уровне закона был принят всего один такой акт, а именно Закон РСФСР «О порядке отзыва депутата местного Совета депутатов трудящихся» (1960 г.) [7]. Этот закон был настолько основательно проработан, что в своей основе, будучи отредактированным новым законом в 1979 г., действовал практически до распада СССР.

При этом в процессе трансформации советского государства в период «оттепели» значительное внимание уделялось повышению роли общественных организаций. Так, на XXII съезде КПСС 1961 г. в числе важнейших был провозглашен и такой призыв: «каждый советский человек должен стать активным участником в управлении делами общества!» [8]. За этой общей, на первый взгляд, фразой, скрывалась концепция предполагаемого партией будущего советской страны (так и неосуществленного). В частности, официальные власти в соответствии с теорией «общенародного государства» прогнозировали, что Советы в будущем перестанут быть органами государственной власти и всецело превратятся в структуры общественной самодеятельности трудящихся, предназначенные для управления делами общества, без каких бы то ни было политических функций. Но это должен был быть постепенный процесс, в котором Советы должны были получать все новые и новые полномочия - с тем, что депутаты как представители народа, более активно включались в непосредственное управление текущих вопросов на всех уровнях (союзном, республиканском, местном). С учетом этой политики издавались и соответствующие законодательные акты. Так, применительно к местным Советам 8 апреля 1968 г. был издан Указ ПВС СССР «Об основных правах и обязанностях сельских и поселковых Советов депутатов трудящихся», а 19 марта 1971 г.- Указ ПВС СССР «Об основных правах и обязанностях районных и районных в городах Советов депутатов трудящихся». Эти акты существенно обновили нормативно-правовую базу в данной сфере общественных отношений. На основе союзных актов были приняты и республиканские законы. Так, 29 июля 1971 г. были приняты следующие Законы РСФСР: «О районном Совете депутатов трудящихся РСФСР» от 29 июля 1971 г. [9], «О городском, районном в городе Совете депутатов трудящихся РСФСР» [10].

Так, в законе о районном Совете в ст. 2 указывалось, что «районный Совет депутатов трудящихся избирается гражданами, проживающими на территории района, на основе всеобщего, равного и прямого избирательного права при тайном голосовании сроком на два с половиной года» [9]. Порядок проведения выборов определялся отдельными законами, которые мы здесь не рассматриваем. Роль отдельного депутата местного Совета признавалась в такого рода актах довольно значимой. В частности, депутат обязан был участвовать в работе Совета, выполнять его поручения, поддерживать связь с избирателями, вести прием граждан, информировать их (в том 
числе в форме отчетов перед избирателями) как о деятельности в целом Совета, так и о своей деятельности как депутата, принимать меры по реализации наказов и предложений избирателей.

Не менее детально определялись и права местного депутата, который, в частности, имел право: вносить на рассмотрение Совета и его исполнительных структур свои предложения по обсуждаемым вопросам, инициировать обсуждение других вопросов, которые он считал актуальными; участвовать в проверке работы предприятий и организаций, расположенных на территории Совета; делать запрос к исполнительному комитету, руководителям его отделов и управлений, предприятий и организаций по любому вопросу, относящемуся к компетенции Совета, и получать соответствующие ответы в срок, установленный Советом и др. Отмеченными выше законами устанавливались также гарантии депутатской деятельности, в частности, применительно к районным Советам указывалось, что депутат на время сессии освобождается от выполнения своих профессиональных обязанностей с сохранением среднего заработка ... Депутат районного Совета, осуществляя свои депутатские обязанности, пользуется правом бесплатного проезда на всех видах местного транспорта общего пользования в границах района ... Депутат районного Совета депутатов трудящихся не может быть по инициативе администрации уволен с работы, а также не может быть на территории района привлечен к уголовной ответственности либо арестован без согласия районного Совета, а в период между сессиями - без согласия его исполнительного комитета» [9].

В целом вопросу более четкого регулирования статуса депутата в советском государстве в 1970-х гг. уделялось значительное внимание - так, на XXIV съезде КПСС было выдвинуто предложение о принятии специального закона, в котором был бы определен правовой статус депутатов, и это предложение в 1972 г. было реализовано в виде принятия соответствующего закона союзного уровня [11], куда были включены большинство норм рассмотренных выше актов. Вместе с тем монополия партии коммунистов и безальтернативные выборы по прежнему имели место, что снижало фактический потенциал депутатов. В таком виде статус депутата Советов всех уровней, включая, включая уровень местных Советов, был воспринят Конституцией СССР 1977г., и в своей основе действовал до конца 1980-х гг., когда в рамках «перестройки» стали происходить кардинальные общественно-политические и социально-экономические изменения, приведшие к распаду советского государства.

$$
* * *
$$

1. Конституция РСФСР (принята V Всероссийским Съездом Советов в заседании от 10.07. 1918 г.) // СУ РСФСР. 1918. № 51. Ст. 582.

2. Декрет ВЦИК от 24 ноября 1917 г. «О праве отзыва делегатов» // СУ РСФСР. 1917. № 3. Ст.49.

3. Резолюция VII съезда Всероссийского съезда Советов «О советском строительстве» от 09.12.1919 г. // СУ РСФСР. 1919. № 64. Ст. 578.

4. Постановление ВЦИК «Об отзыве депутата» от 23.07.1928 г. // СУ РСФСР. 1928. № 104. Ст. 657.

5. Конституция (Основной Закон) СССР (утверждена постановлением Чрезвычайного VIII Съезда Советов СССР от 05.12.1936 г. // Известия ЦИК и ВЦИК. 1936. № 283. 6 декабря.

6. Реабилитация: Политические процессы 30-50-х годов / Под общ. ред. А.Н. Яковлева. М., 1991. С. 430.

7. Закон РСФСР «О порядке отзыва депутата местного Совета депутатов трудящихся» от 27.10. 1960 г. // Ведомости Верховного Совета РСФСР. 1960. № 40. Ст. 587.

8. ХХІІ съезд КПСС: Стенографический отчет. М., 1962. Т. 1.

9. Закон РСФСР «О районном Совете депутатов трудящихся РСФСР» от 29 июля 1971 г. // Ведомости Верховного Совета РСФСР. 1971. № 31. Ст. 653.

10. Закон РСФСР «О городском, районном в городе Совете депутатов трудящихся РСФСР» также от 29 июля 1971 г. // Ведомости Верховного Совета РСФСР. 1971. № 31. Ст. 654.

11. Закон СССР «О статусе депутатов Советов депутатов трудящихся в СССР» от 20.09.1972 г. // Ведомости ВС СССР. 1972. № 39. 